\title{
PLASMA POLYSACCHARIDE FRACTION CONTAINING URONIC ACID, IN NORMAL SUBJECTS AND IN PATIENTS WITH RHEUMATOID ARTHRITIS ${ }^{1}$
}

\author{
By JACQUES BADIN,2 MAXWELL SCHUBERT, AND MARY VOURAS
}

(From the Departments of Chemistry and Medicine and the Study Group on Rheumatic Diseases, New York University College of Medicine, New York, N. Y.)

(Submitted for publication March 10, 1955; accepted March 30, 1955)

Recent work on the ground substance of connective tissue has stressed the importance of mucopolysaccharide components which contain glucuronate such as hyaluronate and chondroitin sulfate. In different tissues these polysaccharides appear to vary widely in degree of polymerization and in relative quantity (1-3). Little is known about the catabolism of the ground substance polysaccharides and their possible elimination through blood and urine.

The total polysaccharide content of plasma has frequently been studied and found to contain mannose, galactose, fucose, and glucosamine (47). In human plasma the polysaccharides are contained mainly in the globulins (8). Albumin normally contains much less (9). Of the total polysaccharide about 10 per cent is in the mucoprotein fraction and is not precipitated by high concentration of ethanol or by 6 per cent perchloric acid (10-13). In these studies no significant amount of hexuronate has been found in any plasma polysaccharide fraction, perhaps due to the unreliability of uronic acid determination in the presence of large amounts of protein, and the drastic methods of protein hydrolysis used. The glucuronate of tungstic acid treated plasma filtrates (14) is not part of a polysaccharide. The only report of glucuronate bound to serum proteins is that of Stary and Yuvanidis (15). They precipitated serum proteins with trichloracetic acid, hydrolyzed them by boiling four hours in concentrated $\mathrm{HCl}$ and used Tollens'

\footnotetext{
1 This investigation was supported (in part) by research grant A-28(C) from the National Institute of Arthritis and Metabolic Diseases, of the National Institutes of Health, U. S. Public Health Service, and (in part) by the Masonic Foundation for Medical Research and Human Welfare and the New York Chapter, The Arthritis and Rheumatism Foundation.

2 Smith-Mundt, Fulbright Fellow. Present address: Medical Faculty, University of Paris, France.
}

naphthoresorcinol reaction on the hydrolysates. They claimed this reaction was specific for glucuronic acid and reported good recovery of free glucuronic acid added to the precipitated protein. They found about 100 to $168 \mu \mathrm{g}$. glucuronic acid bound to $100 \mathrm{mg}$. protein. However they did not study the recovery of added polysaccharide such as chondroitin sulfate and did not point out that the color developed in a serum protein hydrolysate differed from that developed by glucuronic acid. In the present work, difficulties, to be described later, were found with Tollens' method when applied to plasma fractions containing polysaccharides.

Polysaccharides of urine, on the contrary, do contain glucuronate. Tayeau, Biserte, Montreuil, and Marqueville (16) reported a mucoprotein in urine containing mannose, fucose, galactose, acetylhexosamine and hexuronic acid. Kerby (17) found a polysaccharide in urine which contained hexuronic acid and hexosamine and which on paper electrophoresis behaved as chondroitin sulfate. This polysaccharide was not derived from the urinary tract or the prostatic gland.

In the present work a method has been developed which separates from plasma a material which contains polysaccharide with glucuronic acid as a component. In this form the glucuronic acid can be quantitatively determined. The method involves two novel procedures. The first is based on the previous observation (18) that chondroitin sulfate added to plasma is recovered in the euglobulin fraction. The glucuronate-containing material of plasma is also found entirely concentrated in the euglobulin fraction, since examination of the euglobulin-free plasma revealed no glucuronate. The second new procedure is the separation, after protein digestion, of the glucuronate-containing material by the relatively 
selective action of lysozyme in precipitating high molecular weight anionic materials.

\section{EXPERIMENTAL}

The hexuronate-containing fraction of plasma was isolated in the following six steps.

1) Blood (30 to $40 \mathrm{ml}$.) was collected with addition of sodium citrate ( $1 \mathrm{ml}$., 10 per cent solution). The sample was centrifuged, and the plasma separated and diluted with 3 vol. of aqueous sodium citrate ( 0.1 per cent).

2) Using Sandor, Sabetay, and Vargues' procedure (19) the diluted plasma was dialyzed in a cellophane bag against $2 \mathrm{~L}$. of buffer (citric acid, $\mathrm{Na}_{2} \mathrm{HPO}_{4}, \mathrm{M} / 150$, pH $5.8 \pm .1$ ). After dialysis for 3 days at $4^{\circ} \mathrm{C}$. euglobulins were centrifuged and then washed with $5 \mathrm{ml}$. buffer, then with ethanol and ether, dried and weighed (column 3, Table I).

3) The only suitable digestion procedure found was as follows. A solution of crystalline pepsin (3 mg. per $\mathrm{ml}$. in $.1 \mathrm{M} \mathrm{HCl}$ ) was added to the protein in the ratio of $6 \mathrm{mg}$. pepsin for $100 \mathrm{mg}$. protein. Samples were gently shaken at room temperature for 3 days and then neutralized with $1 \mathrm{M} \mathrm{NaOH}$. A solution of crystalline trypsin (3.5 mg. per ml. in $\mathrm{HCl}$-sodium barbital buffer, $\mathrm{M} / 7, \mathrm{pH} 8.4$ ) was then added to give $2 \mathrm{mg}$. trypsin for $100 \mathrm{mg}$. original protein. This gave a pH of about 8 and a sodium barbital molarity of about $M / 35$. Toluene ( $1 \mathrm{ml}$.) was added and digestion continued 3 days at about $30^{\circ} \mathrm{C}$.
4) The hydrolysates were neutralized with acetic acid and made up to $10 \mathrm{ml}$. with water. Perchloric acid, 60 per cent, was added to give a final concentration of 6 per cent. After standing an hour, precipitated proteins were centrifuged, washed with ethanol, dissolved in 1 $\mathrm{ml}$. alkaline saline and protein determined with the biuret reaction. Deduction of this residual protein from the initial sample gave the amount of protein digested (column 4, Table I).

5) The solution of protein hydrolysate containing $\mathrm{HClO}_{4}$ was dialyzed in cellophane bags against $3 \mathrm{~L}$. potassium acetate solution, 0.1 per cent, for 24 hours and then added to $10 \mathrm{vol}$. of a mixture of ethanol ( 8 parts) and ether (2 parts) containing potassium acetate ( 0.5 per cent) in flasks. After 48 hours at room temperature the polysaccharides adhered to the glass and the fluid was poured off. Flasks were dried 1 hour at $40^{\circ} \mathrm{C}$. and polysaccharides were dissolved in $10 \mathrm{ml}$. water.

6) To each solution was added a freshly made, clear solution of lysozyme, $15 \mathrm{mg}$. in $5 \mathrm{ml}$. water. Turbidity appeared immediately and a flocculent precipitate soon formed which was centrifuged easily after 3 hours and washed with water.

The material precipitated by lysozyme was dissolved in $1 \mathrm{ml}$. saline alkalinized with a trace of $\mathrm{NaOH}$ and used for the carbazole test as described below. All samples developed the characteristic pink color as did glucuronic acid. Seven samples of normal human euglobulins gave an average of $57 \mathrm{\mu g}$. glucuronic acid for 100 mg. protein digested (column 5, Table I). Recovery of

TABLE I

Results of analysis, by the procedure described, of the euglobulin of plasma of normals and of subjects with rheumatoid arthritis

\begin{tabular}{|c|c|c|c|c|c|}
\hline & \multicolumn{3}{|c|}{ Euglobulins } & \multicolumn{2}{|c|}{ Hexuronic acid } \\
\hline & $\begin{array}{c}\text { Per } 100 \mathrm{ml} . \\
\text { plasma } \\
(\mathrm{mg} .)\end{array}$ & $\begin{array}{l}\text { Used for } \\
\text { determ. } \\
\text { (mg.) }\end{array}$ & $\begin{array}{c}\text { Digested } \\
\text { by enzyme } \\
\text { (mg.) }\end{array}$ & $\begin{array}{l}\text { Per } 100 \text { mg. } \\
\text { euglobulin } \\
(\mu g .)\end{array}$ & $\begin{array}{c}\text { Per } 100 \mathrm{ml} . \\
\text { plasma } \\
(n g .)\end{array}$ \\
\hline $\begin{array}{l}\text { Rheumatoid subjects } \\
\text { 1. Ben. } \\
\text { 2. Der. } \\
\text { 3. Ga. } \\
\text { 4. In. } \\
\text { 5. Po. } \\
\text { 6. Rot. } \\
\text { 7. Wo. } \\
\text { 8. Av. } \\
\text { 9. Man. } \\
\text { 10. Mas. }\end{array}$ & $\begin{array}{r}431 \\
905 \\
393 \\
785 \\
694 \\
540 \\
533 \\
1,470 \\
500 \\
1,210\end{array}$ & $\begin{array}{r}95 \\
145 \\
51 \\
126 \\
111 \\
54 \\
96 \\
280 \\
100 \\
230\end{array}$ & $\begin{array}{r}92 \\
137 \\
48 \\
120 \\
106 \\
51 \\
92 \\
276 \\
98 \\
221\end{array}$ & $\begin{array}{r}75.0 \\
58.0 \\
152.0 \\
51.7 \\
53.8 \\
68.6 \\
67.5 \\
23.1 \\
34.6 \\
34.1\end{array}$ & $\begin{array}{l}323 \\
525 \\
597 \\
406 \\
373 \\
370 \\
359 \\
339 \\
173 \\
412\end{array}$ \\
\hline Average & 746 & & & 61.8 & 388 \\
\hline $\begin{array}{l}\text { Normals } \\
\text { 1. No. } 3934 \\
\text { 2. MacL. } \\
\text { 3. Cap. } \\
\text { 4. Ken. } \\
\text { 5. Cruz. } \\
\text { 6. Sant. } \\
\text { 7. Sla. }\end{array}$ & $\begin{array}{l}384 \\
430 \\
331 \\
340 \\
425 \\
340 \\
325\end{array}$ & $\begin{array}{l}300 \\
300 \\
133 \\
137 \\
162 \\
137 \\
131\end{array}$ & $\begin{array}{l}295 \\
294 \\
126 \\
130 \\
154 \\
130 \\
124\end{array}$ & $\begin{array}{l}44.8 \\
35.7 \\
66.7 \\
54.1 \\
65.0 \\
46.2 \\
86.5\end{array}$ & $\begin{array}{l}172 \\
153 \\
221 \\
184 \\
276 \\
157 \\
281\end{array}$ \\
\hline Average & 361 & & & 57.0 & 206 \\
\hline
\end{tabular}


potassium chondroitin sulfate ( 1 to $5 \mathrm{mg}$.) added to the original protein samples was between 66 and 100 per cent.

The proteins of the diluted plasma, which remained after removal of the euglobulins, were precipitated with ten volumes of ethanol and then treated by the six steps described. In no case did the products develop the characteristic pink color in the carbazole reaction.

For further characterization, larger amounts of the product containing hexuronic acid were required. The same procedure was used starting with 1 to $2 \mathrm{gm}$. euglobulin. The lysozyme precipitate was centrifuged and dissolved in $5 \mathrm{ml}$. alkalinized saline. On this larger sample glucuronic acid, total polysaccharides, hexosamine and protein could be determined.

\section{ANALYTICAL METHODS}

Tollens' naphthoresorcinol method has been considered to be specific for the determination of glucuronic acid (20). In this test a deep violet color develops in the ether layer whose intensity is proportional to the amount of glucuronic acid. The method as described by Ratish and Bullowa (21) was found unsuitable for our purpose. Addition of chondroitin sulfate to serum protein gave less than 50 per cent recovery of hexuronic acid. From plasma protein hydrolysates, which contain large quantities of other sugars, the colored complex was not extracted with ether. In the presence of added hexoses, complexes seemed to be formed with naphthoresorcinol and hexuronic acid which were not soluble in ether. By adding pyridine, these complexes became soluble in ether and a deep purple color developed which was the sum of the colors due to glucuronic acid and the added hexoses. Attempts to separate the violet complex due to glucuronic acid from the purple complexes due to other sugars by chromatography using toluene and toluene-glycol systems failed.

The carbazole reaction of Dische (22), on the contrary, was found very sensitive and specific for uronic acids. This reaction did not give good results on biological materials since some amino acids and high concentrations of serum lipids interfere with the development of color. Mannose, galactose, fucose, and glucose do not give a pink color, as do hexuronic acids, but rather a pale brown-yellow color with a completely different absorption spectrum (Figure 1). This reaction has been considered to measure uronic acids only when the color developed was bright pink or purple with a peak at $520 \mathrm{~m} \mu$. For determinations on polysaccharide-lysozyme complexes it was found important to have controls in the presence of a quantity of lysozyme similar to that in the precipitates. Figure 2 shows the standard curve for glucuronic acid and its modification by added lysozyme. Lysozyme when heated alone with $\mathrm{H}_{2} \mathrm{SO}_{4}$ developed a faint brownyellow tint that deepened slightly on addition of carbazole but never turned pink. This color limits the sensitivity of the method but never corresponds to more than $5 \mu \mathrm{g}$. of glucuronic acid. The Dische reaction was carried out as follows.

To a sample (10 to $120 \mu \mathrm{g}$. uronic acid in 1 ml.) in a calibrated Klett tube, $6 \mathrm{ml} . \mathrm{H}_{2} \mathrm{SO}_{4}$ were added dropwise, with shaking in an ice bath; the fluid was thoroughly mixed by bubbling air through it with a fine pipette. The tubes were heated for 30 minutes in a boiling water bath, then chilled in ice water. The brownish color which developed was read with a Klett-Sumerson photometer (filter S540) and was usually less than 60 divisions. If the reading was greater, the mixtures were diluted with a solution $\left(\mathrm{H}_{2} \mathrm{SO}_{4} 6\right.$ vol., water 1 vol.) to make the reading less than 60 , and then read. Carbazole $(0.2 \mathrm{ml}$., 0.1 per cent in alcohol) was added to each tube and the fluids mixed by bubbling air through them. The carbazole used was twice crystallized from ethanol and sublimed in vacuo. The tubes were set at $4^{\circ} \mathrm{C}$. for 12 to 15 hours, then a second set of readings was made and the first set deducted. Samples not developing the characteristic pink color were considered as totally lacking in hexuronic acid.

For hexosamine Shetlar, Foster, Kelly, and Everett's micro method (23) was modified. The sample to be analyzed $(1 \mathrm{ml}$.) was hydrolyzed 4 hours with $\mathrm{HCl}(1 \mathrm{ml} ., 8 \mathrm{M})$ at $100^{\circ} \mathrm{C}$. The mixture was decolorized with Darco (50 mg.), centrifuged, the Darco washed with water and the washings added to the hydrolysate. The method, continued as described by Shetlar, allowed determination of 20 to $100 \mu \mathrm{g}$. hexosamine with about 10 to 15 per cent error.

Total sugars determined with the modified tryptophane method $(24,25)$ gave results with an error of about 10 per cent.

Proteins estimated with the biuret method were reliable when solutions were colorless and no turbidity developed with the reagent (26).

The larger samples of precipitate obtained with 


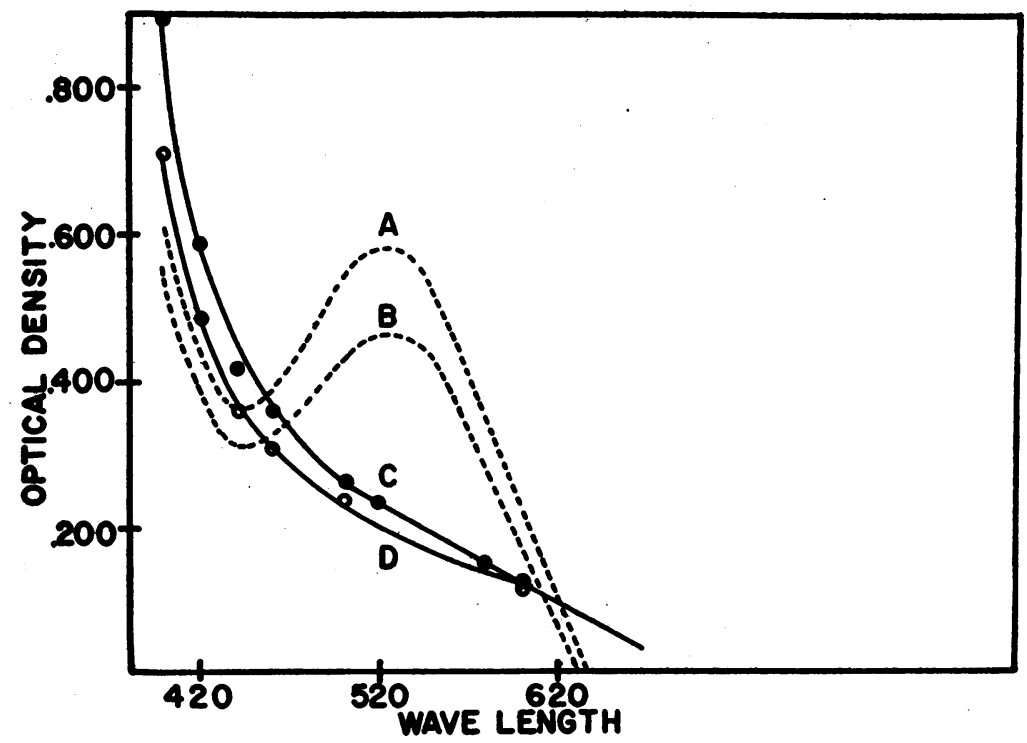

Fig. 1. Spectra of Carbazole Reaction Products in Sulfuric Acid with Different Sugars

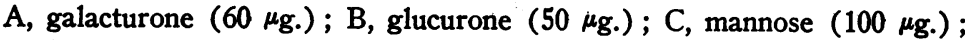
$D$, galactose $(100 \mu \mathrm{g}$.$) . Glucose, glucosamine, and fucose give spectra al-$ most identical with those of mannose and galactose.

lysozyme from 1 to $2 \mathrm{gm}$. of normal human several corrections. The lysozyme (Worthingeuglobulin as described above were analyzed for hexuronate, hexosamine, total sugars, and protein. The analytical results were subjected to ton Biochemical Corp.) was similarly analyzed and found to contain $164 \mu \mathrm{g}$. total sugars and $52 \mu \mathrm{g}$. hexosamine per $100 \mathrm{mg}$., but no detectable

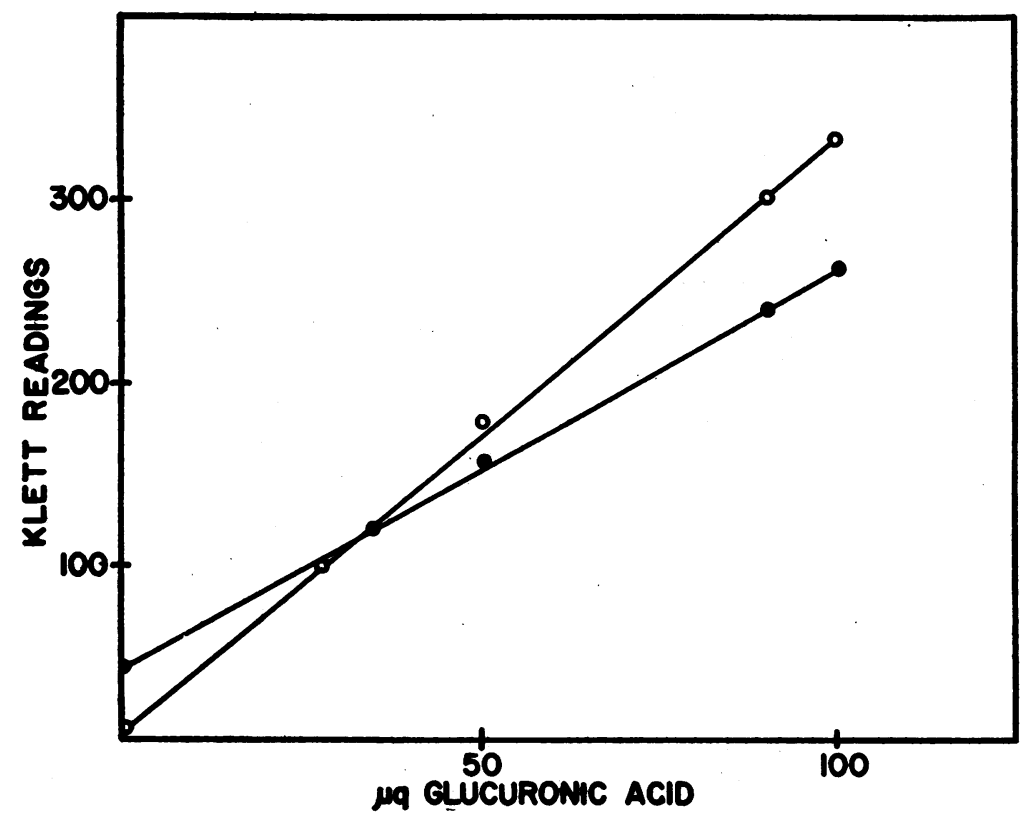

Fig. 2. Influence of Lysozyme on Dische's Carbazole Reaction

$\bigcirc$, glucuronic acid; $\bullet$, glucturonic acid in the presence of a constant amount (5 mg.) of lysozyme. 
TABLE II

Results of analysis of material precipitated with alcohol and the polysaccharide material precipitated with lysozyme*

\begin{tabular}{|c|c|c|c|c|}
\hline $\begin{array}{l}\text { Starting materials } \\
(1 \mathrm{gm} .) \dagger\end{array}$ & $\begin{array}{c}\text { Total } \\
\text { sugars } \\
\text { mg. }\end{array}$ & $\begin{array}{c}\text { Hexuronic } \\
\text { acid } \\
\text { mg. }\end{array}$ & $\begin{array}{c}\text { Hexosamine } \\
\text { mg. }\end{array}$ & $\begin{array}{c}\text { Protein } \\
\text { (Biuret) } \\
\text { mg. }\end{array}$ \\
\hline \multicolumn{5}{|c|}{ Total polysaccharides precipitated in step 5} \\
\hline Euglobulins & 13.50 & $\begin{array}{c}\text { No pink color } \\
\text { develops } \ddagger\end{array}$ & 7.35 & 42.0 \\
\hline \multicolumn{5}{|c|}{ Lysozyme precipitates produced in step 6} \\
\hline \multirow{3}{*}{$\begin{array}{l}\text { Euglobulins } \\
\text { Total plasma proteins (including } \\
\text { euglobulins) } \\
\text { Total plasma proteins with added } \\
\text { chondroitin sulfate (1.33 mg.) }\end{array}$} & .408 & .480 & .483 & 20.8 \\
\hline & .043 & .072 & .191 & 14.4 \\
\hline & & .342 & .400 & 17.5 \\
\hline
\end{tabular}

Lysozyme precipitate of potassium chondroitin sulfate carried through steps 1-6

Chondroitin sulfate $(1 \mathrm{mg}$.)

Calculated

.270

.266

.209

.250

* No attempt was made to calculate the percentages of the several components since the products were never isolated in a dry form.

† Euglobulins were prepared as in steps 1 and 2. Total plasma proteins were prepared by the addition to plasma of ten volumes of ethanol, and the product was washed with ethanol and ether.

$\ddagger$ The failure of a pink color to develop in this material, although glucuronic acid must be present, is probably due to the presence of the large excess of hexoses and also a larger proportion of protein.

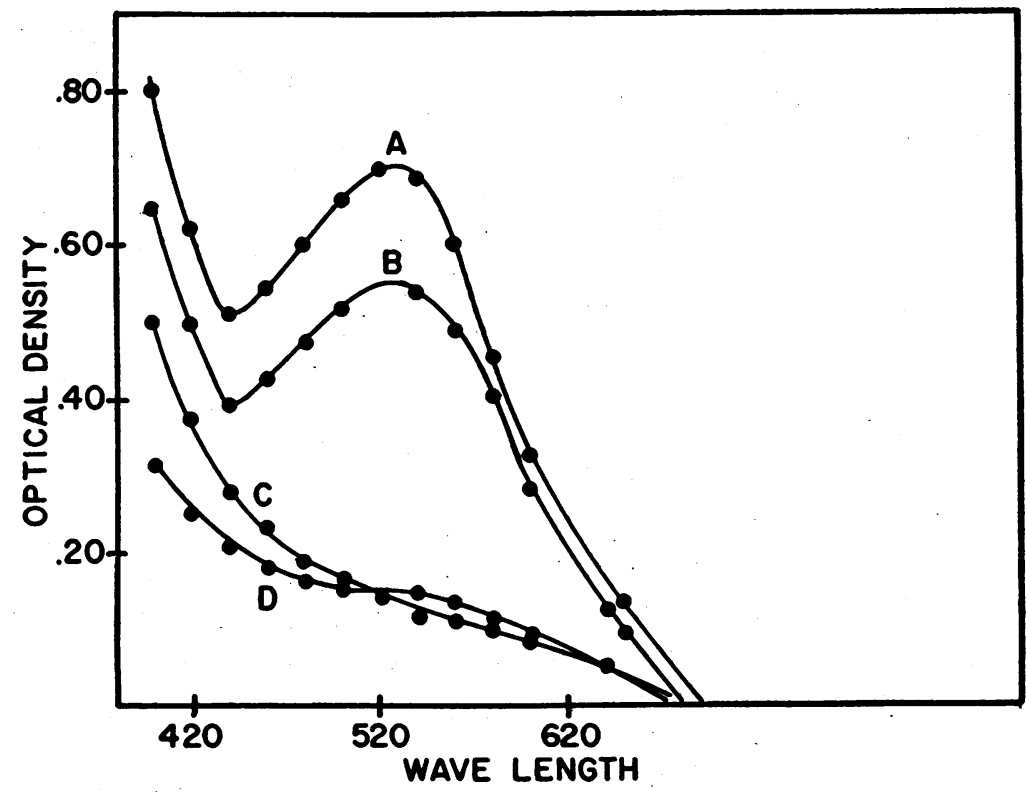

Fig. 3. Spectrum of Carbazole Reaction Product in Sulfuric Acid with the Acid Polysaccharide from Serum Euglobulins and Some Controls

A, euglobulin polysaccharide precipitated with lysozyme; B, $5 \mu \mathrm{g}$. of glucurone and $8 \mathrm{mg}$. of lysozyme; C, $8 \mathrm{mg}$. of lysozyme; D, polysaccharide from dialyzed serum (without euglobulins) and $8 \mathrm{mg}$. of lysozyme. Spectra measured with Beckman spectrophotometer. 
hexuronate. Estimations on lysozyme-polysaccharide precipitates were corrected by deducting the amounts of sugar and hexosamine present in the quantity of lysozyme developing the same color with the biuret reaction. The color of the tryptophane reaction for total polysaccharides is due to hexoses, pentoses, and uronic acids. To measure the sugars, the color corresponding to uronic acids was deducted, $100 \mu \mathrm{g}$. of glucuronic acid developing color corresponding to $70 \mu \mathrm{g}$. mannose (25). Table II contains data on analysis of the material precipitated with lysozyme in step 6 . If the total polysaccharides of step 5 are examined with the Dische reaction, no glucuronic acid can be detected because the pink color of the carbazole reaction does not develop with this product. Only after the selective precipitation with lysozyme in step 6 does hexuronic acid appear in the Dische reaction with the characteristic pink color. The euglobulin fraction was found to contain all the hexuronic acid of the total plasma proteins. The figures for the material isolated from euglobulins with lysozyme show the following proportions: $1.00 \mathrm{~mol}$. hexuronic acid, $1.09 \mathrm{~mol}$. hexosamine, $.91 \mathrm{~mol}$. sugar. These figures cannot be interpreted as indicating that the product isolated is a single polysaccharide.

Figure 3 shows that the spectrum of the color produced by a mixture of glucuronic acid and lysozyme cannot be distinguished from that of the complex of lysozyme and the polysaccharide isolated from euglobulins. This is the evidence that the product isolated with lysozyme contains uronic acid.

\section{RESULTS}

Plasma samples of ten patients with active rheumatoid arthritis and of seven normal subjects were compared. All rheumatoid patients had a positive sheep cell agglutination test and all except No. 9 had a high erythrocyte sedimentation rate. All had marked clinical symptoms except No. 1 (Ben.) and No. 9 (Man.). Their ages ranged from 30 to 60 . All normal subjects were healthy donors at the Hospital Blood Bank. Results in Table I show no difference in the glucuronic acid calculated per $100 \mathrm{mg}$. euglobulins between normals and rheumatoids (column 5, Table I). When calculated per $100 \mathrm{ml}$. of plasma (column 6, Table I) there seems to be a differ- ence; all but one of the patients had a higher plasma polysaccharide glucuronate level than the normals.

\section{DISCUSSION}

The presence of the glucuronate containing polysaccharide exclusively in the euglobulin fraction is an expression of its marked anionic properties. It behaves as free chondroitin sulfate does when added to plasma in vitro (18). Dried on a glass slide the lysozyme complex, prepared as described from euglobulin, gives with toluidine blue 0 the characteristic deep violet metachromatic color. Lysozyme alone does not do so. The identity of the material isolated from the euglobulin is not certain. It has an unexpectedly large protein component. Table II shows that the ratio of protein to combined sugar is about 15 in the lysozyme precipitate derived from euglobulin while in the precipitate produced by lysozyme and chondroitin sulfate the ratio is about 5 (18). The material isolated from euglobulin appears to contain protein not completely removed by enzyme digestion. There is no evidence that the material described is a single substance.

There appears to be an increase in the glucuronate containing polysaccharide in the plasma of patients with rheumatoid arthritis. Only one (No. 9) of ten patients studied had a glucuronate level within the range of the normals. This patient had a normal erythrocyte sedimentation rate and the disease was not active. It is possible that the increase in glucuronate containing polysaccharide in rheumatoid arthritis plasma is related to cartilage destruction known to occur in the active disease.

The increase in glucuronate containing polysaccharide in the plasma of rheumatoid arthritis may be the cause of the larger amount of euglobulin formed in this plasma, just as chondroitin sulfate added to plasma would cause the appearance of a larger amount of euglobulins (18).

\section{SUMMARY}

1. A material behaving as an anionic polysaccharide containing uronic acid; hexosamine and one or more sugars has been found in human euglobulin. The components are in the ratio, $1.09 \mathrm{~mol}$. hexosamine, $1.00 \mathrm{~mol}$. glucuronic acid, 
.91 mol. sugar. No trace of this material has been found in euglobulin-free plasma.

2. An increase in this material has been found in the plasma of ten patients with rheumatoid arthritis. This increase appears as an increased amount of euglobulin and not as euglobulin with an increased amount of polysaccharide.

\section{REFERENCES}

1. Partridge, S. M., The chemistry of connective tissues. 1. The state of combination of chondroitin sulphate in cartilage. Biochem. J., 1948, 43, 387.

2. Gersh, I., Ground substance and the plasticity of connective tissues. Harvey Lectures, 1949-50, 45, 211.

3. Meyer, K., The mucopolysaccharides of the interfibrillar substance of the mesenchyme. Ann. New York Acad. Sc., 1950, 52, 943.

4. Sørensen, M., and Haugaard, G., Uber die Anwendbarkeit der Orcinreaktion zur Bestimmung der Art und Menge von Kohlen-hydratgruppen in Eiweissstoffen. Biochem. Ztschr., 1933, 260, 247.

5. Rimington, C., (a) The isolation of a carbohydrate derivative from serum-proteins. Biochem. J., 1929, 23,430 ; (b) The carbohydrate complex of the serum proteins. II. Improved method for isolation and redetermination of structure. Isolation of glucosaminodimannose from proteins of ox blood. Biochem. J., 1931, 25, 1062.

6. Bierry, $H$., Recherches sur les protéides sanguins à l'état normal et à l'état pathologique. Bull. Acad. de méd., Paris, 1943, 127, 447.

7. Dische, Z., and Osnos, M., Distribution of the protein-bound mucopolysaccharide of human serum among various protein fractions and individual variations of its methylpentose content. Abstract of paper presented at Am. Chem. Soc. Meeting, March, 1953.

8. Hewitt, L. F., Chemistry of antibodies and serumproteins. Nitrogen distribution and amino-acids. II. Protein carbohydrate groups. Biochem. J., 1934, 28, 2080.

9. Jayle, M.-F., and Judas, O., Formule glycoprotéidique du plasma sanguin. Helv. et. chim. Acta, 1946, 29, 1310.

10. Winzler, R., Devor, A., Mehl, J., and Smyth, I., Studies on the mucoproteins of human plasma. I. Determination and isolation. J. Clin. Invest., 1948, 27, 609.

11. Schmid, K., Isolation and characterization of glycoproteins from human plasma. J. Am. Chem. Soc., 1953, 75, 2532.
12. Shetlar, M. R., Payne, R. W., Bullock, J. A., Patrick, D. R., Hellbaum, A. A., and Ishmael, W. K., Comparative studies of serum polysaccharides in rheumatoid arthritis and degenerative joint disease. J. Clin. Invest., 1953, 32, 1208.

13. Badin, J., and Glyn, J., Relationship between plasma mucoproteins and protein sugar in patients with rheumatoid arthritis receiving cortisone. Proc. Soc. Exper. Biol. \& Med., 1954, 86, 150.

14. Fashena, G. J., and Stiff, H. A., On the nature of the saccharoid fraction of human blood. II. Identification of glucuronic acid. J. Biol. Chem., 1941, 137, 21.

15. Stary, Z., and Yuvanidis, M., Uber den Hexuronsäuregehalt der Serumproteine. Biochem. Ztschr., 1953, 324, 206.

16. Tayeau, F., Biserte, G., Montreuil, J., and Marqueville, S., Identification de la substance responsable du phénomène d'obstacle de Donaggio. Compt. rend. Acad. d. sc., 1953, 237, 208.

17. Kerby, G., The excretion of glucuronic acid and of acid mucopolysaccharides in normal human urine. J. Clin. Invest., 1954, 33, 1168.

18. Badin, J., and Schubert, M., Conditions of formation of euglobulin-like precipitates from serum proteins and chondroitin sulfate. J. Clin. Invest., 1955, 34, 1312.

19. Sandor, G., Sabetay, Y., and Vargues, R., Le système des globulines peu solubles du sérum. I. Etude de quelques relations entre les lipides et les protéides dans le sérum sanguin. Bull. Soc. chim. Biol., 1953, 35, 273.

20. Mozolowski, W., The quantitative estimation of glycuronic acid and its conjugated compounds by means of the naphthoresorcinol test of Tollens. Biochem. J., 1940, 34, 823.

21. Ratish, H. D., and Bullowa, J. G. M., Determination of glucuronic acid in biological media. Arch. Biochem., 1943, 2, 381.

22. Dische, Z., A new specific color reaction of hexuronic acids. J. Biol. Chem., 1947, 167, 189.

23. Shetlar, M. R., Foster, J. V., Kelly, K. H., and Everett, M. R., Serum polysaccharide level in the normal state. Proc. Soc. Exper. Biol. \& Med., 1948, 69, 507.

24. Shetlar, M. R., Foster, J. V., and Everett, M. R., Determination of serum polysaccharides by the tryptophane reaction. Proc. Soc. Exper. Biol. \& Med., 1948, 67, 125.

25. Badin, J., Jackson, C., and Schubert, M., Improved method for determination of plasma polysaccharides with tryptophane. Proc. Soc. Exper. Biol. \& Med., 1953, 84, 288.

26. Jayle, M.-F., Badin, J., and Boussier, G., Microdosage des protéines sériques par la méthode du biuret. Bull. Soc. chim. biol., 1951, 33, 881. 